Dochody imigrantów i ich transfery zagraniczne, red. Magdalena Butrymowicz,

Piotr Kroczek, Kraków 2019, s. 19-56 (Biblioteczka Prawa 3).

DoI: http://dx.doi.org/10.15633/9788374387804 .02

Dariusz Tułowiecki

O००0-0003-1875-7776

UNIWERSYTET KARDYNAŁA STEFANA WYSZYŃSKIEGO W WARSZAWIE

\title{
Społeczno-ekonomiczna sytuacja Ukraińców w Polsce
}

Migracja nie jest zjawiskiem nowym. Istniała zawsze, aczkolwiek można zaobserwować jej nasilenie w konkretnych okresach historycznych. Badacze odnotowują obecnie nasilenie migracji związane ze zmianami globalizacyjnymi ${ }^{1}$. Swoboda przepływu ludności wpisuje się bowiem w skomplikowane procesy globalizacyjne. Rodzi to nowe mechanizmy, szanse oraz trudności globalne i lokalne. Globalizacja opiera się bowiem m.in. na swobodnej komunikacji oraz przepływie osób, zasobów i kapitału². Zmienia ona oblicza tożsamości lokalnych ${ }^{3}$, jak i rodzi nowe pytania o sposoby ich definiowania w warunkach swobodnego przepływu ludności ${ }^{4}$.

1 A. Giddens, Socjologia, Warszawa 2004, s. 282.

2 Por. D. Tułowiecki, Bez Boga, Kościoła i zasad? Studium socjologiczne nad religijnościa młodzieży, Kraków 2012, s. 48049.

3 P. Mazurkiewicz, Tożsamość Europy w kontekście migracji, w: Migracje jako nowa kwestia społeczna, red. J. Balicki, Katowice 2008, s. 119-130.

4 Por. M. Butrymowicz, Obywatel, nie obywatel, Polak czy nie Polak, członek Narodu Polskiego czy może obcego? Analiza krytyczna, w: Prawne i ekonomiczne aspekty imigracji do Polski, red. M. Butrymowicz, P. Kroczek, Kraków 2017, s. 14-21. 


\section{Migracja w warunkach globalizacji}

O ile migracje istniały zawsze, wzmagając się co wydaje się ważne ze względu na fakt, iż w przeciągu wielkich odkryć geograficznych, rewolucji przemysłowej i poszukiwań lepszego życia w innych częściach świata ${ }^{5}$ o tyle globalizacja je zintensyfikowała, a nawet uczyniła z niej integralną część własnej tożsamości. Swoboda przepływu ludzi przez granice, ich wędrówki ukierunkowane na rozmaicie zdefiniowane cele, wybór migracji jako sposobu życia lub jej konieczność z racji na ograniczony dostęp do zasobów ekonomiczno-społecznych - uważane są za jedną z zasadniczych przyczyn ruchów ludnościowych w skali globalnej ${ }^{6}$. Globalizacja - powodując coraz większe różnice w rozwoju gospodarczym, a w ślad za tym różnice w poziomie życia - rodzi nasilony ruch ludności z regionów biednych, ubogich, naznaczonych niepewnością, konfliktami militarnymi, do krajów bogatych, stabilnych politycznie i mających wyższe wskaźniki bezpieczeństwa społecznego oraz ekonomicznego. „Wszystkie zaznaczające się obecnie kierunki migracji mają podstawy ekonomiczne, poszukiwanie lepiej płatnych miejsc pracy, uzyskanie dostępu do wyższych dochodów, osiągnięcie przynajmniej zbliżonego poziomu życia do istniejącego w krajach przyjmujących imigrantów”' W Wytuacji, gdy jedne regiony świata dotknięte są biedą i nadmiarem rąk do pracy, w innych - bogatych - potrzeba nowych zasobów siły roboczej. Owo zapotrzebowanie istnieje zarówno ze względu na deficyt demograficzny, jak i „efekt windy”, w wyniku którego pracujący zajmują coraz wyższe stanowiska pracy, zaś niższe,

5 H. Thiollet, Czy na świecie jest coraz więcej migrantów?, w: Migranci, migracje. O czym warto wiedzieć, by wyrobić sobie własne zdanie, red. H. Thiollet, Kraków 2017, s. 9-11.

6 Por. Z. Bauman, Globalizacja. I co z tego dla ludzi wynika, Warszawa 200o, s. 92-120.

7 W. Misiak, Globalizacja więcej niż podręcznik. Społeczeństwo - kultura - polityka, Warszawa 2007, s. 106. 
gorzej płatne oraz niżej cenione pozostają w stanie wakatu i zapełniane są migrantami z krajów uboższych ${ }^{8}$. Migracja uznana została zatem przez badaczy społecznych i ekonomistów za trwały proces wpisany w świat, także Europy ${ }^{9}$.

Ponieważ Polska nie była do tej pory postrzegana jako kraj o wysokim poziomie życia, z dostępem do wysokich świadczeń socjalnych, oraz nie godziła się na przyjmowanie rzesz migrantów ekonomicznych, nie była częstym celem migracji ekonomicznej ${ }^{10}$. To z Polski emigrowano do innych krajów w poszukiwaniu lepszego życia i bezpieczeństwa ekonomiczno-społecznego ${ }^{11}$. Migracje zarobkowe Polaków wyjeżdżających z kraju motywowane były wysokim poziomem bezrobocia w Polsce, wyższymi zarobkami niż w kraju macierzystym, możliwością zasilania budżetów rodzinnych poprzez transfer zarobionych pieniędzy. Ponadto migracje zarobkowe miały i mają znaczenie społeczne: zapoznają z innym niż polski systemem pracy, z nowymi kulturami organizacyjnymi, sztukami motywacji, technologiami, normami kodeksu pracy, przyczyniają się do poznawania sposobów rozwiązywania problemów na szczeblu lokalnym oraz umożliwiają doskonalenie języka kraju docelowego migranta ${ }^{12}$.

Sytuacja ta uległa jednak pewnej zmianie. O ile Polska nie jest otwarta na migrantów z Afryki Północnej oraz Bliskiego Wschodu, a także

8 H. Thiollet, Czy ludzie migruja z krajów biednych do bogatych?, w: Migranci, migracje. O czym warto wiedzieć, by wyrobić sobie własne zdanie, red. H. Thiollet, Kraków 2017, s. 12.

9 Por. M. Duszczyk, K. Matuszczyk, Migration in the 21st century from the perspective of CEE countries - an opportunity or a threat?, Warsaw 2014.

10 M. Ćwiek, P. Ulman, Imigracja do Polski w świetle badań statystycznych, w: Prawne i ekonomiczne aspekty imigracji do Polski, red. M. Butrymowicz, P. Kroczek, Kraków 2017, s. 24.

11 T. Biedrzycki, Wyjazdy Polaków za granicę po 1 maja 2004, w: Migracje jako nowa kwestia społeczna, red. J. Balicki, Katowice 2008, s. 65.

12 W. Misiak, Globalizacja więcej niż podręcznik..., dz. cyt., s. 108. 
nie jest w polu ich zainteresowań, to w ostatnich latach stała się celem wędrówek dla mieszkańców sąsiedniej Ukrainy. To właśnie Ukraina jest obecnie największym źródłem migrantów do Polski ${ }^{13}$. W Polsce możliwość migracji zarobkowej cudzoziemców narodziła się dopiero po 1989 roku. Stopniowo, przez ostatnie lata, migracje te ze zjawiska marginalnego stały się wyraźną i trwałą tendencją, a Polska z państwa emigracyjnego, między innymi dzięki wzrostowi poziomu dobrobytu, przekształca się w państwo emigracyjno-imigracyjne.

Od lat dziewięćdziesiątych xx wieku w Polsce można zaobserwować kształtowanie się niekorzystnych zmian w strukturze wiekowej ludności, spowodowane dwiema przyczynami. Pierwszą z nich jest starzenie się społeczeństwa oraz coraz mniejszy poziom aktywności zawodowej Polaków. Drugą przyczyną jest przystąpienie Polski do Unii Europejskiej, czego wynikiem była znacząca fala emigracji Polaków do państw członkowskich Unii Europejskiej odnotowywana po roku 2004. Ta ogromna fala wyjazdów za granicę nie pozostała bez wpływu na sytuację na polskim rynku pracy. Z naszego kraju wyjechało wielu wysoko wykwalifikowanych pracowników. Jednym z podstawowych czynników, jaki oddziałuje na decyzję o podjęciu pracy w innym kraju, są wyższe zarobki, rekompensujące niedogodności życia na obczyźnie, oraz chęć poznania lepszego życia. Deficyt „rąk do pracy” spowodował, iż wielu pracodawców zaczęło poszukiwać pracowników poza granicami Polski, co przełożyło się na intensyfikację zjawiska przypływu przedstawicieli innych nacji, poszukujących lepszych warunków życia. Polska staje się krajem coraz bardziej popularnym wśród imigrantów. Polski rynek pracy

13 K. Pawlicki, K. Wątorek, Legalność zatrudnienia imigrantów w Polsce, w: Ekonomické, sociální a právní problémy demografického vývoje v České republice, Evropské unii a ve světě, red. J. Ondřej, M. Hála, Praha 2015, s. 215-217. 
jest otwarty dla obywateli państw Unii Europejskiej zgodnie z zasadą swobodnego przepływu ludności. Jednak do naszego kraju przybywają głównie obywatele państw nienależących do UE, najczęściej z Ukrainy czy też z niektórych państw azjatyckich - Chin i Wietnamu ${ }^{14}$.

Obywatele Ukrainy przodują w statystykach wjazdów, osiedlania się, wiz, osób podejmujących w Polsce pracę i studia oraz aplikujących o polskie obywatelstwo. Popularności Polski jako kraju docelowego dla Ukraińców sprzyja wiele czynników. Jest to przede wszystkim bliskość geograficzna i kulturowa. Migranci z Ukrainy przyjeżdżający do Polski nie mają większych problemów z komunikacją z Polakami oraz adaptacją do polskich warunków życia. Są także na ogół pozytywnie postrzegani przez polskie społeczeństwo, co jest ważnym czynnikiem sprzyjającym podjęciu decyzji o przyjeździe i pozostaniu w Polsce. Migracja Ukraińców do Polski ma w większości przypadków charakter zarobkowy, krótkookresowy, ale regularny (cykliczny, często sezonowy). Aczkolwiek i w tej kwestii następują zmiany, a część migrantów, pracując na umowę o pracę, planuje zostać tutaj na dłużej, nawet na stałe. Ukraińcy przyjeżdżają do Polski, by podjąć pracę (najczęściej w sektorach budowlanym, opieki domowej i rolnictwie), zarobić i wspomóc tym samym swój budżet i/lub budżet ukraińskiego gospodarstwa domowego, którego są częścią. Wykorzystują w tym celu coraz bardziej przyjazne warunki wjazdu, możliwość podejmowania studiów i legalnego zatrudnienia, w tym system oświadczeń pracodawców ${ }^{15}$. Dlatego ważna

14 J. Szpakowska, T. Buchwald, R. Romanowski, Atrakcyjność polskiego rynku pracy dla obywateli Ukrainy - przyczyny, mechanizmy, konsekwencje migracji zarobkowych, „Optimum. Studia Ekonomiczne” (2016), nr 2 (80), s. 164-165.

15 Z. Brunarska, M. Grotte, M. Lesińska, Wstęp, w: Migracje obywateli Ukrainy do Polski w kontekście rozwoju społeczno-gospodarczego: stan obecny, polityka, transfery pieniężne, red. Z. Brunarska, M. Grotte, M. Lesińska, Gdańsk 2012, s. 4. 
wydaje się analiza sytuacji Ukraińców migrujących do Polski, badanie stanu i jakości tej migracji, jakości życia Ukraińców w Polsce oraz ich sytuacji społeczno-ekonomicznej.

Obecnie wiele ośrodków akademickich, instytucji państwowych, centrów polityki społecznej wobec migrantów zajmuje się badaniami sytuacji Ukraińców w Polsce. Włączają się w to państwowe agendy monitorujące rozwój ekonomiczny Polski, przestrzeganie praw człowieka w Polsce, badacze mniejszości etnicznych i narodowych, polsko-ukraińskie stowarzyszenia ekonomiczne, jak i firmy zajmujące się pośrednictwem pracy. Celem niniejszego opracowania jest analiza dotychczas publikowanych danych na temat pobytu Ukraińców w Polsce w celu ukazania ich sytuacji społeczno-ekonomicznej. Ważne jest bowiem, jak swoją sytuację w Polsce określają sami Ukraińcy. W jaki sposób definiują swój status społeczny i ekonomiczny? Jak planują swój pobyt? Jak postrzegają Polskę jako kraj imigracji? Jak odbierają Polaków i jak definiują stosunek Polaków do siebie? Czy rozważają stałe osiedlenie się w Polsce? Czy postrzegają Polskę jako lepszy kraj do życia niż rodzima Ukraina?

Podejmując próbę odpowiedzi na te pytania badawcze, posłużono się analizą materiałów uzyskanych w ramach projektów badawczych innych ośrodków akademickich, instytucji państwowych i firm prywatnych. Są to przede wszystkim publikacje i wyniki badań: Ośrodka Badań nad Migracjami Uniwersytetu Warszawskiego, Narodowego Banku Polskiego, Kolegium Europy Wschodniej im. Jana Nowaka-Jeziorańskiego we Wrocławiu, Raporty Narodowego Banku Polskiego, Rzecznika Praw Obywatelskich, Instytutu Spraw Publicznych.

\section{Geneza migracji Ukraińców do Polski}

Wraz ze zmianami w Europie Środkowowschodniej i rozpadem Związku Radzieckiego przed mieszkańcami dawnych republik zSRR, w tym 
Ukraińcami, otworzyły się możliwości podróżowania za granicę, także w celach zarobkowych. Możliwość ta miała istotne znaczenie wobec pogorszenia się warunków życia w okresie transformacji. Zaraz po 1991 roku mobilność przybierała przede wszystkim formę krótkoterminowych wyjazdów zagranicznych. Miały one głównie cel handlowy i ograniczały się do terenów przygranicznych. Z czasem znaczna część tych wyjazdów przekształciła się w tymczasowe migracje zarobkowe przyjmujące postać cykliczną. W tym pierwszym okresie głównym celem wyjazdów dla obywateli Ukrainy były Rosja i Polska oraz Węgry, Czechy i Słowacja, bowiem w krajach sąsiedzkich obywatele Ukrainy nie potrzebowali wiz. Z czasem kierunki ukraińskiej migracji zarobkowej uległy dywersyfikacji i objęły także bardziej odległe kraje Europy ${ }^{16}$.

Przyczyny współczesnej migracji Ukraińców do Unii Europejskiej należy upatrywać po pierwsze - w postępującym zjawisku globalizacji i otwarciu się Ukrainy na międzynarodowy rynek pracy po 1991 roku; po drugie - w pojawieniu się zapotrzebowania na zagraniczną siłę roboczą w krajach południowej Europy i towarzyszącej temu aktywności pośredników oraz w przeprowadzanych na terenie tych krajów akcjach regulujących napływ pracowników z zagranicy. Po trzecie - stoją za tym zmiany warunków przemieszczania się obywateli Ukrainy do państw Grupy Wyszehradzkiej w związku z ich wejściem do Unii Europejskiej. W 2007 roku przemieszczanie to zostało objęte dodatkowo nowymi zasadami w strefie Schengen. Do 2003 roku obywatele Ukrainy mogli wjeżdżać na terytorium Polski bez wiz. Wprowadzony po 2003 roku system wizowy wobec migrantów z Ukrainy określany był jako liberalny. Wizy były bowiem bezpłatne, a otrzymanie wizy wielokrotnej nie stanowiło problemu. Istotne zmiany przyniosło wejście Polski do strefy

16 Z. Brunarska, Ukrainssy migranci w Polsce: sytuacja obecna, w: Migracje obywateli Ukrainy do Polski w kontekście rozwoju społeczno-gospodarczego: stan obecny, polityka, transfery pieniężne, red. Z. Brunarska, M. Grotte, M. Lesińska, Gdańsk 2012, s. 6 . 
Schengen, które narzuciło zunifikowane podejście wobec obywateli państw trzecich, chcących przebywać na terenie strefy Schengen, co zrównało Polskę pod względem dostępności z krajami tzw. starej Unii. $\mathrm{Z}$ tego powodu oraz za sprawą m.in. niższych stawek płac polski rynek pracy często przegrywał w konkurencji z innymi krajami uE (np. Włochami lub Hiszpanią), które były w stanie zaoferować obywatelom Ukrainy atrakcyjniejsze warunki zatrudnienia ${ }^{17}$.

Kolejny krok w otwarciu polskiego rynku pracy na Unię Europejską, w tym Polskę, nastąpił w 2016 i 2017 roku. Po podpisaniu w 2014 roku przez uE i Ukrainę układu o stowarzyszeniu (wymagającego ratyfikacji przez wszystkie państwa członkowskie), w 2016 roku weszła w życie handlowa część umowy stowarzyszeniowej Ukrainy z UE ${ }^{18}$. 11 czerwca 2017 roku został zniesiony obowiązek wizowy dla obywateli Ukrainy posiadających paszport biometryczny, jeśli ich pobyt w uE (poza Wielką Brytanią i Irlandią) nie przekroczy 90 dni w ciągu każdego 180-dniowego okresu. Ułatwionej możliwości wjazdu do Polski nadal towarzyszą ograniczenia dotyczące możliwości zarobkowania. Ukraińcy są uprawnieni do wykonywania pracy na terytorium Polski, jeśli przedłożą odpowiednie dokumenty, np. oświadczenia o zamiarze powierzenia wykonywania pracy lub odpowiednie zezwolenie na pracę ${ }^{19}$.

Otwarcie granic UE dla Ukraińców oraz brak spójnej polityki migracyjnej Polski wobec Ukraińców rodzą jednak określone konsekwencje. Po pierwszym miesiącu funkcjonowania zliberalizowanych przepisów granicę Unii Europejskiej przekroczyło bez wiz ponad

17 Z. Brunarska, Ukraińscy migranci w Polsce..., dz. cyt., s. 6.

18 Częściowe zniesienie wiz dla Ukraińców, http://e-prawnik.pl/wiadomosci/informacje/czesciowe-zniesienie-wiz-dla-ukraincow.html (2.06.2018).

19 I. Trzaska, Zniesienie wiz dla Ukraińców. Od 11 czerwca będą mogli wjechać m.in. biznesowo do UE, www.money.pl/gospodarka/unia-europejska/wiadomosci/artykul/wizy-dla-ukrancow-ue,118,o,2329206.html (2.06.2018). 
95 tysięcy Ukraińców. Można zatem mówić o fali nasilenia migracyjnego. O ile w chwili obecnej nie można jednoznacznie stwierdzić, by wywarło to jakiś wielki wpływ na przesuwanie się fal migrantów z Polski do innych państw zachodnich, o tyle można zidentyfikować przynajmniej dwa związane z tym aspekty negatywne dla naszego kraju. „Po pierwsze, z niektórych regionów Polski (np. okolic Szczecina) zdążyła już przesiedlić się większość imigrantów z Ukrainy wybrali państwa zachodnie, takie jak Niemcy, gdzie mogą liczyć na wyższe stawki. Po drugie, zaostrza się konkurencja o ukraińskich pracowników. Już w tej chwili Niemcy proponują imigrantom z Ukrainy stypendia, szkolenia językowe czy też dopłaty do noclegów. Zatrudnianiu imigrantów sprzyjają również niemieckie przepisy - producent rolny może tam przez 70 dni roboczych zatrudniać robotnika bez konieczności opłacania za niego składek. Wiąże się to oczywiście z mniejszym obciążeniem wynagrodzenia pozapłacowymi kosztami pracy, a zatem z wyższą kwotą otrzymywaną netto. O imigrantów z Ukrainy gotowi są powalczyć również pracodawcy z Czech czy Węgier ${ }^{20}$.

Patrząc na migrację Ukraińców do Polski w ostatnich latach, można zauważyć, że jeszcze przed aneksją Krymu i wojną na wschodzie Ukrainy Polska pozostawała istotnym celem migracji ekonomicznej Ukraińców. Według przeprowadzonego w 2008 roku przez Ukraiński Ośrodek na rzecz Reform Społecznych (UCSR) i Państwowy Komitet Statystyczny Ukrainy (Ukrstat) badania gospodarstw domowych na Ukrainie Polskę wybierało ok. 8\% ukraińskich migrantów zarobkowych. Tym samym zajmowała ona czwarte miejsce na liście ich krajów docelowych (po Rosji - 48\%, Włoszech - 13\% oraz Czechach - 12\%). Wysoka pozycja Polski

20 J. Bińkowski, Ukraińska migracja do Polski. Analiza zjawiska w kontekście rynku pracy, Warszawa-Wojnowice 2017, s. 38. 
spowodowana jest przede wszystkim jej bliskością geograficzną (co wiąże się z niskimi kosztami przejazdów), podobieństwem języków polskiego i ukraińskiego oraz istnieniem sieci migracyjnych, ułatwiających potencjalnym migrantom organizację wyjazdu za granicę. Także zmiany dotyczące na przykład uproszczonego trybu zatrudniania cudzoziemców, które Polska systematycznie wprowadzała od 2006 roku, przyczyniły się do wzrostu atrakcyjności Polski jako kraju docelowego dla ukraińskich tymczasowych migrantów zarobkowych. Dla Polski z kolei Ukraina stanowi najważniejsze zagraniczne źródło migracji zarobkowej i osiedleńczej ${ }^{21}$.

Jednak zmiany w ruchu wizowym po roku 2017 działają na niekorzyść Polski. Wydaje się, że państwo polskie nie wykorzystało momentu, kiedy Polska była dla Ukraińców naturalnym wyborem przy analizowaniu potencjalnych nowych miejsc pobytu.

Dopóki droga do pozostałych państw Unii Europejskiej była dla nich relatywnie zamknięta, dopóty Polska miała możliwość absorbować maksymalnie dużą liczbę imigrantów - tak przecież potrzebnych gospodarce i systemowi emerytalnemu. Niestety, wskutek braku jednolitej polityki i swoistego niezdecydowania zarówno rządzących, jak i części aparatu urzędniczego, potencjał nie został w pełni wykorzystany. W tej chwili nie jesteśmy już opcją naturalną, ale zaledwie jedną z możliwych. Nie ulega bowiem wątpliwości, że zniesienie wiz do Unii Europejskiej dla obywateli Ukrainy to zaledwie jeden z pierwszych kroków podejmowanych przez silne państwa pogrążone w kryzysie demograficznym tylko po to, by uzyskać dostęp do większej liczby ludzi w wieku produkcyjnym²2.

21 Z. Brunarska, Ukraińscy migranci w Polsce..., art. cyt., s. 6-7.

22 J. Bińkowski, Ukraińska migracja... dz. cyt., s. 39-40. 
Migracja Ukraińców do Polski ma także swoje uwarunkowania w sytuacji wewnętrznej Ukrainy. O ile po rozpadzie bloku wschodniego Polska gospodarka rozwijała się i następował stopniowy wzrost poziomu życia w Polsce, o tyle Ukraina zatrzymała się pod tym względem w miejscu. W 1989 roku był to kraj zamożniejszy od Polski ${ }^{23}$. Niestety, korupcja, oligarchizacja życia polityczno-ekonomicznego, niejednolitość kulturowa, wadliwy system polityczny i brak rzeczywistych przemian gospodarczych doprowadziły do tego, że współczesna Ukraina jest pod względem gospodarczym państwem o wiele słabszym niż Polska ${ }^{24}$. Sytuacja pogorszyła się jeszcze i ujawniła słabość państwa ukraińskiego po aneksji Krymu i w obliczu wojny na wschodzie Ukrainy ${ }^{25}$. Kolejne kryzysy polityczne, słabość władzy centralnej, afery ekonomiczne sprawiały, że dokonało się wówczas widoczne osłabienie lokalnej waluty ${ }^{26}$ oraz realny spadek dochodów gospodarstw domowych poprzez drastyczny spadek (niemal o połowę) siły nabywczej hrywny ${ }^{27}$.

Niska jakość ukraińskiej gospodarki i państwa ma bardzo wyraźne przełożenie właśnie na dochody gospodarstw domowych. Dochodzi do ogromnej dysproporcji w zakresie wynagrodzeń. Gdy płaca minimalna jest na Ukrainie poniżej wartości 1000 PLN, wiele osób nie osiąga dochodów w tej wysokości, lecz zarabia znacznie mniej. Z tego powodu Polska jest dla Ukraińców naturalnym miejscem docelowym migracji ${ }^{28}$.

23 D. Słomski, Kiedyś ukraińska gospodarka była silniejsza od polskiej. Balcerowicz powtórzy plan? www.money.pl/gospodarka/wiadomosci/artykul/kiedys-ukrainska-gospodarka-byla-silniejsza,225,o,2068193.html (1.06.2018).

24 J. Bińkowski, Ukraińska migracja... dz. cyt., s. 14.

25 D. Tułowiecki, Solidarność europejska a wojna na Ukrainie - kryzys, próba czy deficyt? Perspektywa polska i innych państw Europy Środkowowschodniej, „Śląskie Studia Historyczno-Teologiczne" (2015), nr 2 (48), s. 461-468.

26 M. Kozak, Niebezpieczne gry z hrywna, www.obserwatorfinansowy.pl/tematyka/ makroekonomia/niebezpieczne-gry-z-hrywna/ (1.06.2018).

27 K. Bartman, Przyzwoitość z PKB, www.obserwatorfinansowy.pl/tematyka/makroekonomia/przyzwoitosc-a-pkb/ (1.06.2018).

28 J. Bińkowski, Ukraińska migracja do Polski... dz. cyt., s. 14. 
W trudnej sytuacji międzynarodowej, napięć ukraińsko-rosyjskich, aneksji Krymu i wspomaganych przez Rosję separatystycznych działań militarnych we wschodniej Ukrainie istnieje ważna grupa Ukraińców ubiegająca się o ochronę międzynarodową. Od 2014 roku w Polsce przebywa grupa obywateli ukraińskich, w tym około $8 \%$ to osoby narodowości innej niż ukraińska (tatarskiej, ormiańskiej, rosyjskiej), którzy ubiegają się o ochronę międzynarodową. Jednak poza nielicznymi wyjątkami Polska nie udziela obecnie ochrony międzynarodowej obywatelom Ukrainy z uwagi na to, iż konflikt nie obejmuje całego terytorium Ukrainy, a tym samym zachowana jest możliwość przeniesienia się w inny, bezpieczny, region tego kraju ${ }^{29}$. Z racji na ograniczoną liczebność tej kategorii obywateli ukraińskich w Polsce nie będzie ona poddana niniejszym analizom badawczym.

O skali ukraińskiej migracji zarobkowej można dowiedzieć się między innymi z Bilansu Płatniczego RP Narodowego Banku Polskiego za II kwartał 2017 roku. W dokumencie tym wskazano, że transfery bankowe przychodów z tytułu pracy tzw. nierezydentów z Ukrainy (osób pracujących w Polsce nie dłużej niż rok) tylko za trzy miesiące w 2017 roku wyniosły 3 mld zł, co stanowiło 90,6\% wszystkich środków przekazanych za granicę przez pracujących w Polsce cudzoziemców. Jest to wynik wysokiej i wciąż rosnącej liczby obywateli Ukrainy obecnych na polskim rynku pracy. Według danych Ministerstwa Rodziny, Pracy i Polityki Społecznej w II kwartale 2017 roku polscy przedsiębiorcy zarejestrowali 446,2 tys. oświadczeń o chęci powierzenia pracy obywatelom Ukrainy (95\% wszystkich zarejestrowanych oświadczeń) i było to o $46,5 \%$ więcej niż w analogicznym okresie roku poprzedniego. Łącznie w dwóch pierwszych kwartałach 2017 roku liczba zarejestrowanych oświadczeń dotyczących Ukraińców wyniosła 904,9 tys. i w stosunku do pierwszego półrocza 2016 wzrosła o 47,3\%. Jednocześnie

29 K. Pawlicki, K. Wątorek, Legalność zatrudnienia... art. cyt., s. 222. 
w pierwszym półroczu 2017 roku obywatelom Ukrainy wydano 91,4 tys. zezwoleń na pracę w Polsce (84,5\% wszystkich wydanych zezwoleń), tj. o $114,4 \%$ więcej niż przed rokiem ${ }^{30}$.

\section{Opinie Ukraińców na temat pracy w Polsce}

Wedle badań отто Work Force - firmy zajmującej się pośrednictwem pracy w skali europejskiej, która prowadzi monitoring zadowolenia Ukraińców sprowadzanych do pracy w Polsce ${ }^{31}$ - głównym czynnikiem motywującym obywateli Ukrainy do wyjazdu do Polski jest czynnik ekonomiczny. Wedle materiału empirycznego zgromadzonego w latach 2015, 2016 i 2017 na próbie 1117 respondentów - pracowników z Ukrainy zatrudnionych w Polsce - wzrosło znaczenie wysokości wynagrodzenia jako głównego motywatora imigracji do Polski. Głównym powodem, dla którego Ukraińcy decydują się na wyjazd do Polski, są zarobki kilkakrotnie wyższe niż na Ukrainie. Realne płace w Polsce - inaczej niż na Ukrainie - stale rosną. Dotyczy to przede wszystkim płac pracowników z branży produkcyjnej oraz posiadających umiejętności techniczne. W lutym 2015 roku wysokość wynagrodzenia była ważnym powodem do wyjazdu dla 39\% badanych, dziewięć miesięcy później - dla 53\%, w 2017 roku zaś - już dla 94\%. Z raportu отто Work Force można wnioskować, że zarobki są najważniejszym powodem wyjazdu do pracy do Polski dla mężczyzn oraz osób starszych. W podejmowaniu decyzji o emigracji coraz większą rolę odgrywa bezrobocie na Ukrainie oraz pogarszająca się sytuacja polityczna. Kilkuprocentowe (9\% w 2015 roku, 7\% w 2017 roku), choć wciąż niewielkie znaczenie miało na przełomie 2016 i 2017 roku możliwość tranzytu przez Polskę do Europy Zachodniej.

30 Narodowy Bank Polski. Bilans Płatniczy Rzeczypospolitej Polskiej za II kwartał 2017 r., Warszawa 2017, s. 19, www.nbp.pl/publikacje/bilans_platniczy/bilans_platniczy2017_2.pdf (2.06.2018).

31 www.ottoworkforce.pl (2.06.2018). 
Znaczenie tego czynnika - zdaniem analityków - może w przyszłości wzrosnąć, zwłaszcza że od 2017 roku przed Ukraińcami pojawiła się szersza możliwość legalnej pracy na Zachodzie oraz tańszy transport na Ukrainę. Wedle analiz statystycznych przeprowadzonych na danych empirycznych uzyskanych przez отто Work Force możliwość tranzytu wyżej cenią kobiety niż mężczyźni, a także osoby młodsze i lepiej wykształcone ${ }^{32}$. Najprawdopodobniej jest to związane z zakładaną możliwością względnie stałego osiedlenia się w krajach Europy Zachodniej.

Obraz ten uzupełniają badania na Ukraińcach w Polsce zlecone przez Narodowy Bank Polski. Przeprowadzono je w II połowie 2015 roku na próbie 710 obywateli Ukrainy zamieszkujących przede wszystkim ognisko mazowieckie, uwzględniając wyspowy charakter migracji. W badaniu wzięli udział obywatele Ukrainy przebywający w Polsce, z wyłączeniem osób, które przyjechały tu w celach turystyczno-wypoczynkowych, w odwiedziny do rodziny lub na leczenie. Badania objęły także Ukraińców studiujących w Polsce (125 osoby). Badanie ankietowe zostało przeprowadzone metodą RDS (Respondent Driven Sampling). Składało się ono z dwóch modułów: ilościowego i jakościowego. Ankietyzacja prowadzona była metodą wywiadów bezpośrednich w specjalnie do tego celu przygotowanym pomieszczeniu. Wykorzystana metoda została dodatkowo zmodyfikowana, aby ująć w badaniu także osoby zatrudnione w sektorze rolniczym, które ze względu na charakter wykonywanej pracy nie bywają na co dzień w aglomeracji warszawskiej33.

32 T. Dudek, Raport: Opinia pracowników z Ukrainy na temat pracy w Polsce 2017, s. 4, https://www.ottoworkforce.pl/wp-content/uploads/2017/o4/Raport-от TO-Work-Force-Opinia-pracowników-z-Ukrainy-na-temat-pracy-w-Polsce-2017-2. pdf (2.06.2018).

33 I. Chmielewska, G. Dobroczek, J. Puzynkiewicz, Obywatele Ukrainy pracujacy $w$ Polsce - raport $z$ badania NBP. Badanie zrealizowane $w 2015$ r., Warszawa 2016, s. 7-8, www.nbp.pl/aktualnosci/wiadomosci_2016/20161212_obywatele_ukrainy_pracujacy_w_polsce_-_raport_z_badania.pdf (o2.06.2018). 
Wykres 1. Powody wyjazdów do Polski (dane w \%)

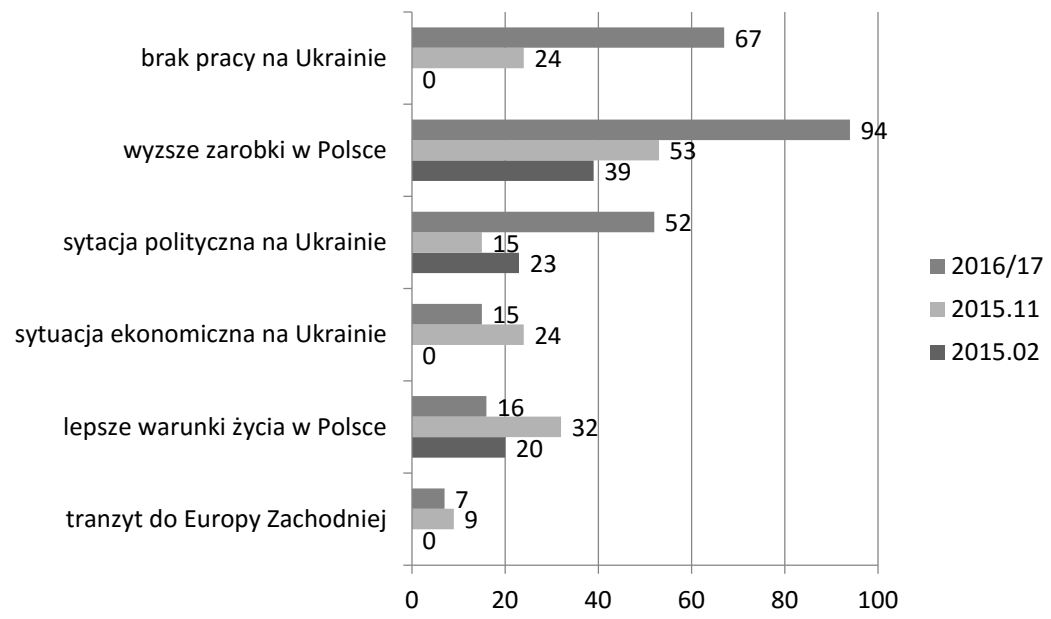

Źródło: отто Work Force

Z badań zleconych przez Narodowy Bank Polski wyłania się obraz migrantów, którzy nigdy wcześniej nie opuszczali własnego kraju. Polska jest krajem pierwszej migracji zarobkowej przyjeżdżających tutaj Ukraińców. Jedynie 11,6\% osób z grupy nowych migrantów jeździło wcześniej w celach zarobkowych do innych krajów, głównie do Rosji. Aż 41,3\% ankietowanych stanowią Ukraińcy, którzy do tej pory nie przyjeżdżali do Polski w celach zarobkowych. Tylko 13\% ankietowanych przyjechało tu po raz pierwszy w 2014 roku, a 28,3\% w 2015 roku. Pozostałe osoby $(58,7 \%)$ to migranci, którzy przed 2014 rokiem byli w Polsce co najmniej raz. Na podstawie zebranych przez NBP danych empirycznych można wnioskować o pojawieniu się zupełnie nowej fali imigrantów, którzy nie posiadają doświadczenia w pracy zarobkowej w Polsce. Co więcej, osoby te w większości nie podejmowały zatrudnienia w żadnym innym kraju ${ }^{34}$.

34 I. Chmielewska, G. Dobroczek, J. Puzynkiewicz, Obywatele Ukrainy..., dz. cyt., s. 9-10. 
Obywatele Ukrainy, dla których pobyt w Polsce w 2015 roku nie był pierwszy, mogą być określeni jako migranci „doświadczeni”. Aż 14,6\% spośród nich było w Polsce po raz pierwszy już pomiędzy 1989 a 1999 rokiem, kolejne 85,4\% w latach 200o-2013. Co więcej, osoby te pojawiały się w Polsce z dużą regularnością. Przeciętnie w czasie ankietyzacji osób mających za sobą doświadczenie przyjazdu do Polski okazało się, że obecny pobyt był już ich dziewiątą wizytą w Polsce. Rekordziści byli tutaj nawet 43 razy, co oznacza, że od 1989 roku przyjeżdżali nawet dwa-trzy razy w roku. Wedle deklarowanych motywacji migracyjnych decyzja o przyjeździe jest podyktowana głównie motywami ekonomicznymi, takimi jak brak pracy (29,4\% odpowiedzi) lub niezadowolenie z poziomu wynagrodzenia na Ukrainie $(53,9 \%)^{35}$.

Dalsza analiza danych wykazała, że nowi migranci, którzy tak licznie pojawili się w ostatnich dwóch latach w Polsce, różnią się od pozostałych nie tylko poziomem doświadczenia w przyjazdach do pracy oraz wskaźnikami motywacji. Pomiędzy tymi dwiema grupami widoczne są także różnice na poziomie podstawowych cech demograficznych. Ważną zmianą, jeśli chodzi o nowych migrantów, jest znaczący wzrost udziału mężczyzn. Podczas gdy w grupie „doświadczonych” migrantów stanowili oni mniejszość (32,9\%), wśród nowo przybyłych ich udział wzrósł do 57,9\% (wzrost o 25 punktów procentowych). Mimo tak istotnego wzrostu liczby mężczyzn w ostatnich latach, w ogólnej liczbie migrantów w niewielkim stopniu przeważają kobiety. W całej przebadanej populacji stanowiły one $56,8 \%$, podczas gdy udział mężczyzn wyniósł $43,2 \%{ }^{36}$.

Jeśli chodzi o strukturę wiekową migrantów, najliczniej reprezentowane są osoby najstarsze, powyżej 45 . roku życia $(35,7 \%)$ oraz naj-

35 I. Chmielewska, G. Dobroczek, J. Puzynkiewicz, Obywatele Ukrainy..., dz. cyt., S. 9-11.

36 I. Chmielewska, G. Dobroczek, J. Puzynkiewicz, Obywatele Ukrainy..., dz. cyt., s. 10. 
młodsze, poniżej 25 lat (24,3\%). Okazuje się jednak, że gdy porówna się ze sobą dwie wydzielone grupy, struktura wiekowa migrantów okazuje się bardzo zróżnicowana. Nowi migranci są zdecydowanie młodsi. Średni wiek dla grupy nowo przybyłych wyniósł 32,8 lat, podczas gdy dla doświadczonych migrantów wynosił on 42,7 lat (aż 10 lat różnicy). Największą zmianą jest wzrost liczby osób bardzo młodych, poniżej 25. roku życia, których udział wśród doświadczonych migrantów wynosi 14\% a wśród nowo przybyłych 39\% (wzrost o $25 \%$.). Bardzo duża zmiana widoczna jest także w kolejnej grupie wiekowej. Udział osób w wieku 26-35 lat wzrósł z 15,0\% wśród doświadczonych migrantów do $26 \%$ wśród nowo przybyłych (więcej o 11 \%). Ogółem wśród osób posiadających już historię migracyjną udział osób poniżej 35. roku życia stanowił 29,0\% ankietowanych, podczas gdy w drugiej z grup wyniósł on $65 \%{ }^{37}$. „Odmłodzenie” migrantów z Ukrainy widoczne jest także w zestawieniu z danymi z 2008 roku. Wedle badań Międzynarodowej Organizacji nad Migracjami dziesięć lat temu migrowali do Polski przede wszystkim Ukraińcy w wieku 26-40 lat (46,4\%), a Ukraińcy do 25. roku życia stanowili tylko 17,1\%. Trzecia część przyjeżdżających do Polski to migranci w wieku $41-65$ lat $(36,5 \%)^{38}$.

W zdecydowanej większości Ukraińcy przyjeżdżający do pracy w Polsce to osoby dobrze wykształcone. W sumie $37,7 \%$ ma wykształcenie wyższe, a 53,94\% wykształcenie średnie (ogólnokształcące lub zawodowe). Jedynie $8,4 \%$ ma wykształcenie zawodowe lub niższe. Lepiej wykształceni są młodsi stażem migranci. W grupie tej aż 47,1\% osób ukończyło studia wyższe, a tylko $7,4 \%$ ma wykształcenie co najwyżej zawodowe. W grupie doświadczonych migrantów udziały te wynoszą 31,0\% dla osób z wykształceniem wyższym i 9,1\% dla osób z najniż-

37 I. Chmielewska, G. Dobroczek, J. Puzynkiewicz, Obywatele Ukrainy..., dz. cyt., s. 10.

38 I. Grabowska-Lusinska, Poland, [w:] Migration end the Economic Crisis in the European Union: Implications for Policy, ed. J. Koehler, F. Laczko, Ch. Aghazarm, J. Schad, Brussels 2010, s. 144. 
szym wykształceniem. Najsłabiej wykształconą grupą wśród migrantów z Ukrainy są osoby pracujące w sektorze rolniczym. Udział osób $\mathrm{Z}$ wykształceniem zawodowym lub niższym wynosi w tej grupie 13,4\%. Należy jednak podkreślić, że nadal można tę grupę uważać za dobrze wykształconą. Aż 63,4\% stanowią w niej osoby z wykształceniem średnim, a 23,3\% osoby po studiach wyższych ${ }^{39}$.

Badania отто Work Force wykazały, że Ukraińcy coraz częściej pracują zgodnie z własnym wykształceniem. W roku 2017 było to $29 \%$ pracowników, co oznacza wzrost o 21\% względem roku 2015. Pomiary от то Work Force potwierdzają także dobre lub bardzo dobre wykształcenie Ukraińców przebywających w Polsce. Korzystający w 2017 roku $\mathrm{z}$ usług отто Work Force w pośrednictwie pracy to w $44 \%$ pracownicy z wykształceniem wyższym, 20\% - średnim, 33\% - zawodowym, $4 \%$ - podstawowym. Wzrost liczby osób zatrudnionych zgodnie z wykształceniem pozwala na wniosek, że pracodawcy coraz efektywniej wykorzystują potencjał imigrantów z Ukrainy. Zatrudnienie wykwalifikowanych imigrantów wpływa na wzrost innowacyjności, ogólny rozwój oraz dyfuzję wiedzy w przedsiębiorstwach ${ }^{40}$.

Ponieważ głównym powodem przyjazdu obywateli Ukrainy do Polski są przyczyny ekonomiczne, Ukraińcy aktywnie poszukują pracy i szybko ją w Polsce znajdują. Znaczna większość migrantów przebywających $\mathrm{w}$ aglomeracji warszawskiej to osoby pracujące. Niemal połowa $(45,6 \%$ osób) ma pracę stałą, a 47,9\% pracuje dorywczo. Znikomy odsetek stanowią Ukraińcy prowadzący własną działalność gospodarczą (o,3\%). Łącznie 93,8\% osób biorących udział w badaniu to osoby aktywne zawodowo. Zaledwie 6,2\% to osoby bezrobotne. Stopa bezrobocia dla całej populacji migrantów z Ukrainy jest na bardzo niskim poziomie, zbliżonym do naturalnej stopy bezrobocia. Warto tu przypomnieć,

39 I. Chmielewska, G. Dobroczek, J. Puzynkiewicz, Obywatele Ukrainy..., dz. cyt., s. 11.

40 T. Dudek, Raport: Opinia pracowników..., dz. cyt., s. 8. 
Wykres 2. Praca zgodnie z wykształceniem (dane w \%)

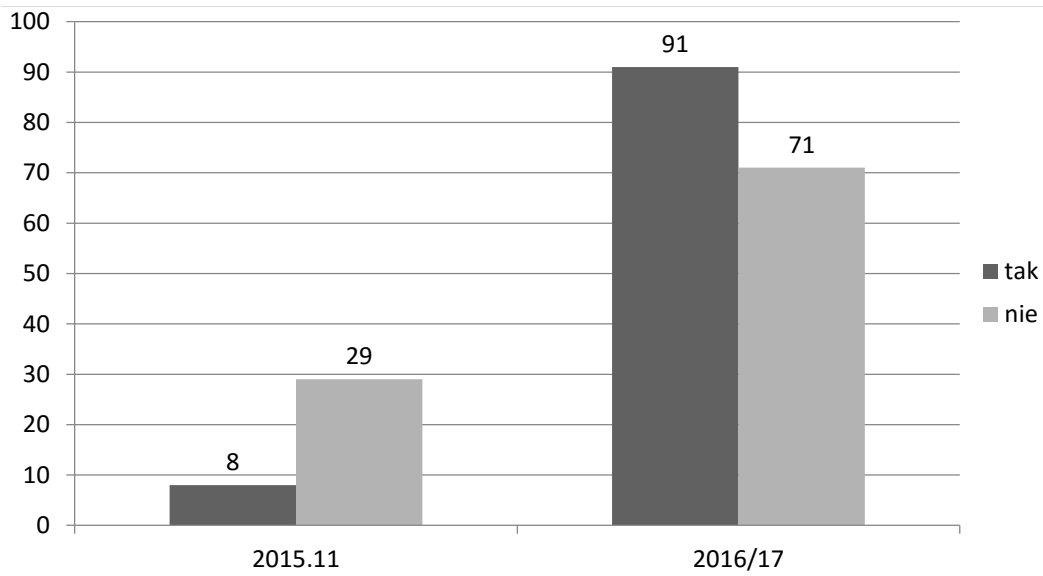

Źródło: отто Work Force

że w czasie gdy realizowane było badanie, stopa bezrobocie dla polskiej gospodarki wynosiła według danych GUS 9,6\%. Niemniej raport NBP zauważa, że bezrobocie wśród osób, które przyjechały do Polski po raz pierwszy po 2014 roku, jest prawie dwukrotnie wyższe $(8,2 \%)$ niż w przypadku doświadczonych migrantów (4,7\%). Może to wynikać z faktu, że osoby doświadczone w przyjazdach zarobkowych do Polski sprawniej poruszają się na polskim rynku pracy i łatwiej mogą znaleźć pracę dzięki kontaktom $\mathrm{z}$ byłymi pracodawcami ${ }^{41}$.

Niski poziom bezrobocia wśród Ukraińców może się wiązać ściśle ze sposobem otrzymywania wizy na wjazd do Polski. Zdecydowana większość przyjeżdża na podstawie oświadczenia pracodawcy o chęci zatrudnienia cudzoziemca (62,6\%). Zatem powinni oni mieć zagwarantowaną pracę na okres pobytu w Polsce. Badania NBP wskazały jednak, że migranci nie zawsze podejmują pracę u pracodawcy, który złożył to oświadczenie. Nie zawsze jest też to ich jedyna praca. Często

41 I. Chmielewska, G. Dobroczek, J. Puzynkiewicz, Obywatele Ukrainy..., dz. cyt., s. 15. 
zatem pomimo w pełni legalnej formy przyjazdu do Polski podejmują oni pracę w sposób nie w pełni legalny. Jeśli chodzi o aspekt ekonomiczny pobytu Ukraińców w Polsce, to badania NBP pozwalają wnioskować, że respondenci najczęściej znajdują zatrudnienie u pracodawcy, z którym skontaktował ich ktoś z rodziny lub znajomych. Aż 70,1\% osób znalazło pracę właśnie w ten sposób. Kolejne 15\% odpowiedziało na ogłoszenie pracodawcy. Z pomocy pośredników, czy to oficjalnych czy nieoficjalnych, skorzystało w sumie 10,6\% migrantów. Pozostali znaleźli zatrudnienie na jeszcze innej drodze. Widać jednak wyraźnie, że najważniejszą rolę odgrywają kontakty bezpośrednie ${ }^{42}$.

Jakość zatrudnienia, warunki pracy i poziom dochodów są podstawą, na której buduje się opinia Ukraińców o czasie pobytu, pobycie stałym, a w sytuacji pobytu czasowego - o ewentualnych ponownych przyjazdach do Polski. Wedle pomiarów z 2017 roku niemal połowa (48\%) pracowników z Ukrainy planuje zostać w Polsce na stałe. To o 38\% więcej niż w 2015 roku. Wzrosła również liczba osób, które zamierzają do Polski przyjeżdżać regularnie i pracować (wzrost z 32\% do 40\%). Przeszło dziesiąta część badanych (11\%) badanych planuje pozostać do końca trwania wizy. Zaobserwowano także istotną dodatnią korelację pomiędzy wykształceniem a planowaną długością pobytu, mianowicie im wyższe wykształcenie mają pracownicy z Ukrainy, tym dłużej chcą pozostać w Polsce ${ }^{43}$. Zadowolenie z warunków pracy w Polsce potwierdzają także zestawienia Urzędu ds. Cudzoziemców z 2017 roku. Od 2012 roku liczba wniosków o udzielenie pozwolenia na pobyt czasowy ze względu na pracę składanych przez obywateli Ukrainy wzrosło niemal trzynastokrotnie (z 3323 w 2012 r. - do 42334 w 2016 r.), podczas gdy pozostałych cudzoziemców dwukrotnie (z 8923 do 16365). Wyraźny

42 I. Chmielewska, G. Dobroczek, J. Puzynkiewicz, Obywatele Ukrainy..., dz. cyt., s. $15-16$.

43 T. Dudek, Raport: Opinia pracowników..., dz. cyt., s. 5. 
Wykres 3 Planowany czas pobytu w Polsce (dane w \%)

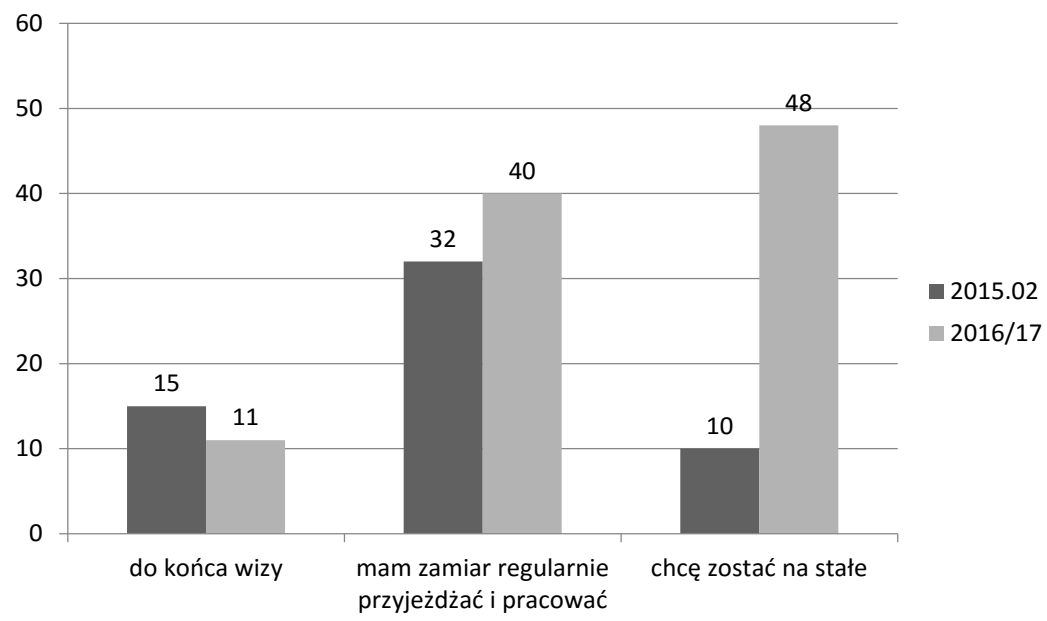

Źródło: отто Work Force

wzrost wniosków ma miejsce także ze względu na inny motywacje: edukację - wzrost z 1649 do 8594, łączenie rodzin - z 2482 do $6870^{44}$

W strukturze zatrudnienia migrantów z Ukrainy, według próby przebadanej przez NBP w aglomeracji warszawskiej, największą część stanowią osoby pracujące $\mathrm{w}$ sektorze usług dla gospodarstw domowych (37,6\%). Drugą pod względem liczebności grupą jest sektor usług remontowo-budowlanych (23,6\%), a trzecią sektor rolniczy (19,3\%). Trzeba również wskazać jako ważne inne sektory zatrudnienia: hotelarstwo i gastronomię (łącznie 12,4\%) oraz handel (7,2\%). W przemyśle pracuje tylko 4,8\% przebadanej populacji migrantów. Badania pozwalają także wnioskować o zmianach w sektorach zatrudnienia między tymi, którzy przyjechali do Polski przed 2013 rokiem, i migrantami z 2014

44 Urząd do spraw Cudzoziemców, Raport na temat Ukrainy, Warszawa 2017, s. 7, https://udsc.gov.pl/wp-content/uploads/2014/12/Ukraina-26.03.2017.pdf (12.06.2018). 
i 2015 roku. Największy spadek zanotowano w sektorze gospodarstw domowych. O ile odsetek „wczesnych” migrantów zatrudnionych w tym segmencie wynosił 51,3\%, o tyle późniejszej migracji tylko 18,3\%. Wzrost nastąpił natomiast w przemyśle ( $\mathrm{z} 3,8 \%$ do 6,2\%), usługach remontowo-budowlanych ( $\mathrm{z}$ 15,3\% do 35,2\%), handlu hurtowym i detalicznym (z 5\% do $10,4 \%$ ), hotelarstwie i gastronomii (z 6,8\% do 20,3\%). Może to być związane z mniejszym niż dotychczas udziałem w tej grupie kobiet, których najczęstszym miejscem pracy są właśnie gospodarstwa domowe. Mężczyźni, których udział w grupie nowych migrantów wzrósł istotnie, znacznie częściej pracują w sektorze usług remontowo-budowlach. Obserwowana zmiana nie wynika więc z mniejszego zainteresowania pracą w gospodarstwach domowych, lecz jest efektem zmiany w strukturze płci migrantów. Zróżnicowanie sektorowe, jeśli chodzi o aktywność kobiet i mężczyzn, jest bardzo mocno zauważalne, ale też zgodne z oczekiwaniami. Sektor usług na rzecz gospodarstw domowych jest prawie w całości zdominowany przez kobiety, natomiast w sektorze usług remontowo-budowlanych zatrudniani są wyłącznie mężczyźni ${ }^{45}$.

Ważnym aspektem w analizie sytuacji imigrantów na polskim rynku pracy są osiągane przez nich zarobki. Średni dochód netto obywateli Ukrainy w aglomeracji warszawskiej w 2017 roku to 2105 PLN. Najwięcej zarabiają cudzoziemcy pracujący w sektorze remontowo-budowlanym (2729 PLN), a najmniej osoby świadczące usługi dla gospodarstw domowych (1826 PLN). W przemyśle płace wynoszą 2183 PLN, w handlu hurtowym i detalicznym 2000 PLN, w rolnictwie, sadownictwie i ogrodnictwie 1992 PLN, w hotelarstwie i gastronomii - 1941 PLN. We wszystkich sektorach z wyjątkiem rolnictwa doświadczeni migranci zarabiają więcej niż niedoświadczeni. Mimo to średnie zarobki ogółem drugiej grupy są wyższe (2133 PLN wobec 2086 PLN). Wynika to z faktu, że wśród doświadczonych migrantów najbardziej powszechny jest sektor gospo-

45 I. Chmielewska, G. Dobroczek, J. Puzynkiewicz, Obywatele Ukrainy..., dz. cyt., s. 17. 
darstw domowych, gdzie zarobki są niższe, a wśród niedoświadczonych migrantów dominuje zatrudnienie w sektorze usług remontowo-budowlanych, który charakteryzuje się stosunkowo wysokimi zarobkami ${ }^{46}$.

Wedle statystyk średnie zarobki migrantów z Ukrainy utrzymywały się w 2017 roku na poziomie 2105 PLN miesięcznie i były zbliżone do mediany zarobków w polskiej gospodarce. Według danych GUS wynosiła ona w 2014 roku brutto 3292 PLN (co daje około 2300 PLN na rękę). Jednak te wyniki wskazują, że aby osiągnąć taki dochód, Ukraińcy muszą pracować dużo więcej, niż wynosi normalny etat w Polsce. Średnio przebadany imigrant pracował 54 godziny tygodniowo, czyli więcej niż średnio Polscy pracujący na etacie. Jednak i w tym przypadku widoczne są różnice pomiędzy różnymi grupami migrantów. Osoby z większym doświadczeniem migracyjnym (pierwsze przybycie do 2013 roku) pracują średnio więcej godzin niż „nowi” migranci (57 godzin tygodniowo wobec 53). Wynika to w dużej mierze $\mathrm{z}$ większego udziału w tej grupie kobiet pracujących w sektorze gospodarstw domowych, a właśnie w tym sektorze pracuje się najwięcej - średnio 58 godzin tygodniowo. Opiekuńczy charakter prac domowych, w tym opieka nad seniorami i prowadzenie gospodarstwa domowego, który rozwinął się w tym sektorze, wymaga czasem pracy przez większą część doby. W innych ważnych sektorach, takich jak usługi remontowo-budowlane oraz rolnictwo, gdzie dominują głównie mężczyźni, średni czas pracy jest również wysoki i wynosi 57 godzin ${ }^{47}$.

Warta monitoringu jest także struktura wydatków Ukraińców pracujących w Polsce. Z zarobionych pieniędzy średnio 34,2\% przeznaczają oni „na życie”, czyli wydatki takie, jak: opłata za mieszkanie, stałe opłaty, np. za energię i media, wyżywienie, zakupy, transport. Możliwość

46 I. Chmielewska, G. Dobroczek, J. Puzynkiewicz, Obywatele Ukrainy..., dz. cyt., s. 20 .

47 I. Chmielewska, G. Dobroczek, J. Puzynkiewicz, Obywatele Ukrainy..., dz. cyt., s. 20 . 
stosunkowo niskich wydatków na życie w Polsce jest w dużej mierze związana z powszechnym zjawiskiem otrzymywania przez imigrantów dodatkowych świadczeń, np. w formie zakwaterowania, wyżywienia lub transportu do pracy, co ułatwia oszczędzanie znacznej części dochodów. Ze świadczeń takich korzysta 53,1\% pracujących, z czego dwie trzecie otrzymuje więcej niż jedno świadczenie. Najpopularniejsze udogodnienie zapewniane przez pracodawcę to zakwaterowanie i wyżywienie. Z obu tych świadczeń korzysta $29,5 \%$ zatrudnionych, a z przynajmniej jednego z dwóch 47,8\%. Oprócz tego pracodawcy pomagają w załatwieniu formalności (prawnych) - 6,4\%, udostępniają dodatkowe świadczenia medyczne $-3 \%$. Brak jakichkolwiek świadczeń dodatkowych ze strony pracodawców zadeklarowało 31,2\% badanych ${ }^{48}$.

Obok faktów, jakie towarzyszą pracy Ukraińców w Polsce, ważne jest także poznanie ich opinii o sposobie traktowania przez pracodawców. Na podstawie zgromadzonego przez ośrodki badawcze materiału empirycznego można wnioskować, że ogólnie wzrasta zadowolenie pracowników z Ukrainy pracą w Polsce. Obserwowalny jest wzrost z poziomu 84\% w 2015 roku do 94\% w 2017 roku. Poziom satysfakcji z pracy w Polsce jest taki sam wśród kobiet, jak i mężczyzn. Wzrósł on wedle danych отто Work Force - we wszystkich grupach wiekowych i poziomu wykształcenia ${ }^{49}$.

от то Work Force zapytało także szczegółowo o ocenę Ukraińców ich sytuacji pracowniczej i powody zadowolenia/niezadowolenia z pracy. Porównanie wyników badań z dwóch okresów badań (listopad 2015 i przełom 2016/2017) wskazuje na wzrost zadowolenia w odniesieniu do niemal wszystkich aspektów pracy. Pracownicy są najbardziej zadowoleni z wynagrodzenia (nastąpił wzrost z 40\% w 2015 roku do 90\% w 2017 roku), ze stosunku Polaków do ukraińskich imigrantów (wzrost

48 I. Chmielewska, G. Dobroczek, J. Puzynkiewicz, Obywatele Ukrainy..., dz. cyt., s. 21.

49 T. Dudek, Raport: Opinia pracowników..., dz. cyt., s. 6. 
Wykres 4. Zadowolenie z pracy w Polsce (dane w \%)

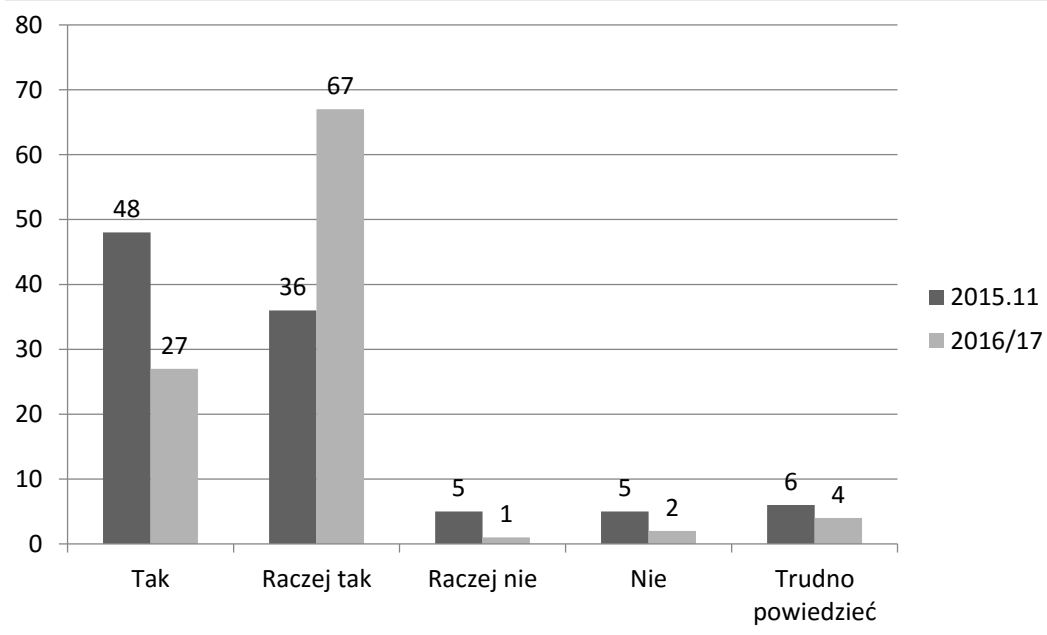

Źródło: отто Work Force

Z 52\% do 89\% w 2017 roku), a także z relacji ze współpracownikami (wzrost z 63\% do 89\% w 2017 roku). Statystyczne badanie korelacji zadowolenia i płci wykazało, że kobiety są istotnie bardziej od mężczyzn zadowolone ze swoich relacji ze współpracownikami. Pracownicy cenią również swoje relacje z przełożonym (wzrost z 61\% w 2015 roku do $87 \%$ w 2017 roku), a także rodzaj wykonywanej pracy (wzrost satysfakcji z 38\% do $78 \%$ w 2017 roku). Im starsi pracownicy, tym mniejsze zadowolenie $\mathrm{z}$ wykonywanej pracy. Pracownicy są zadowoleni z obciążenia obowiązkami, (wzrost z 36\% do 75\% w 2017 roku). Nastąpił także wzrost w pozytywnej ocenie warunków pracy: z 62\% w 2015 roku do 68\% w 2017 roku. Spadek zadowolenia wystąpił w przypadku i tak nisko do tej pory ocenianych możliwości rozwoju: z 27\% w 2015 roku do 23\% w 2016/2017 roku. Analiza statystyczna wykazała, że im starsi pracownicy, tym mniej są zadowoleni z możliwości rozwoju ${ }^{50}$.

50 I. Chmielewska, G. Dobroczek, J. Puzynkiewicz, Obywatele Ukrainy..., dz. cyt., s. 5. 
Jednakże w kontraście do tych opinii pozostają opinie Rzecznika Praw Obywatelskich wyrażane na podstawie badań Związku Ukraińców w Polsce. Wedle jego analiz pozytywnemu nastawieniu Ukraińców do Polski nie odpowiada wzrost postaw antyukraińskich wśród Polaków. Na relacjach pomiędzy Polakami a migrantami z Ukrainy ciąży bolesna przeszłość historyczna obu narodów ${ }^{51}$.

Dla części przedstawicieli polskiego społeczeństwa to mniejszość ukraińska jest pierwszym adresatem oczekiwań i zarzutów, jeżeli chodzi o wyjaśnienie trudnych kwestii z przeszłości. Wiele stereotypów i obrazów wydarzeń odnoszących się do Ukrainy, jako państwa jest projektowanych na mniejszość. Z kolei przedstawiciele mniejszości emocjonalnie reagują na wszelkie przejawy działań skierowanych przeciwko Ukrainie ${ }^{52}$.

Ponieważ przyczyny migracji do Polski mają przede wszystkim naturę ekonomiczną, zapytano Ukraińców pracujących w Polsce nie tylko o ich warunki pracy, ale także wsparcie ekonomiczne, którego udzielają rodzinom pozostającym na Ukrainie. Wsparcie to jest wyraźne, o czym świadczą badania transferów finansowych z Polski, a także ograniczony wskaźnik procentowy kosztów życia (34,2\%). Wedle badań NBP pieniądze do rodziny na Ukrainie przekazuje dwie trzecie osób $(66,4 \%)$. Można zauważyć istotne różnice pomiędzy poszczególnymi podgrupami, jeśli chodzi o skłonność do transferowania środków.

51 Sytuacja mniejszości ukraińskiej i migrantów ukraińskich w Polsce - konferencja $w$ Biurze RPO, www.rpo.gov.pl/pl/content/sytuacja-mniejszosci-ukrainskiej-i-migrantow-ukrainskich-w-polsce-konferencja-w-biurze-rpo (10.06.2018).

52 P. Tyma, Wprowadzenie, [w:] Raport. Mniejszość ukrainska i migranci z Ukrainy w Polsce Analiza dyskursu, red. P. Tyma, Warszawa 2018, s. 39, http://naszwybir.pl/ wp-content/uploads/2018/o3/raport_mniejszosc_ukrainska-ilovepdf-compressed-1. pdf (11.06.2018). 
Zdecydowanie częściej pieniądze przekazują doświadczeni migranci $(78,4 \%)$, kobiety $(74,2 \%)$ oraz osoby pochodzące $z$ zachodnich regionów Ukrainy $(78,6 \%)$. Wysoki udział osób dokonujących przekazów zarobków w tych trzech podgrupach jest ze sobą powiązany, ponieważ wśród doświadczonych migrantów obserwowany jest dużo wyższy udział kobiet niż mężczyzn oraz osób z zachodniej części Ukrainy. Mając na względzie, że część obywateli Ukrainy jest w Polsce od niedawna i być może nie zdążyła jeszcze zgromadzić środków, które mogłaby przekazać rodzinie w kraju, zapytano także o prawdopodobieństwo dokonywania przekazów w najbliższej przyszłości. Spośród osób, które zadeklarowały, że do tej pory nie przekazywały środków, $61,3 \%$ zamierza to zrobić w najbliższej przyszłości. Spośród tych, którzy już przekazują, aż 91,5\% zamierza w dalszym ciągu wysyłać pieniądze na Ukrainę. Bazując na deklaracjach imigrantów, można się spodziewać, że odsetek osób, które przekazują środki zarobione w Polsce, wzrośnie nawet do $81,5 \%{ }^{53}$.

Jeśli chodzi o wysokość pojedynczego transferu, to wynosi ona średnio 1793 PLN, mediana zaś to 1500 PLN. Rozpiętość transferowanych kwot jest jednak duża. Prawie połowa ankietowanych (45,5\%) przekazała ostatnio do kraju kwotę nieprzekraczającą 1000 PLN, przy czym duża część wskazań dotyczyła transferów nie większych niż 500 PLN (o-250 PLN: 7,5\%; 251-500 PLN: 14,8\%) . Kwoty o wyższej wartości - między 1000 a 2000 PLN przekazuje 29,0\% osób, a kolejne 25,5\% dokonuje transferów wyższych niż 2000 PLN. Jednak naprawdę wysokie kwoty, przekraczające 5000 PLN, stanowią tylko 3,2\% deklaracji54.

Z analizy wyników dotyczących częstotliwości przekazów wyłania się model transferowania, według którego migranci najczęściej odkładają

53 I. Chmielewska, G. Dobroczek, J. Puzynkiewicz, Obywatele Ukrainy..., dz. cyt., s. 24.

54 I. Chmielewska, G. Dobroczek, J. Puzynkiewicz, Obywatele Ukrainy..., dz. cyt., s. $23-24$. 
część zarobionych środków i wysyłają je do rodziny co 2-3 miesiące. $\mathrm{Z}$ taką częstotliwością transferów dokonuje aż 46,9\% osób. Zdarzają się jednak i takie osoby, które przekazują środki co miesiąc (20,4\%), a nawet częściej (3,1\%). Zdecydowanie wyższą częstotliwością w przekazywaniu środków charakteryzują się mniej doświadczeni migranci. W grupie tej aż 38,1\% osób przekazuje pieniądze raz na miesiąc lub częściej. Wśród doświadczonych pracowników odsetek ten wynosi 17,3\%. Zdecydowanie więcej jest natomiast w tej drugiej grupie osób przekazujących pieniądze co 2-3 miesiące - 52\% wobec 35,4\% w grupie migrantów bez doświadczenia. Pozostałe osoby dokonują przekazów z mniejszą częstotliwością, jednak odsetek osób, które robią to naprawdę rzadko, tj. rzadziej niż raz na rok, jest niski i w obu grupach wynosi nieco ponad $6 \% 55$.

Spośród osób, które dokonują transferów, 57,5\% deklaruje, że przed przekazaniem lub zawiezieniem zarobionych pieniędzy na Ukrainę wymienia złote na inną walutę. Najczęściej jest to dolar amerykański (42,5\%). Mniejsze znaczenie ma euro (9,1\%) i hrywna (5,0\%). Pozostali $(42,5 \%)$ nie dokonują wymiany i przekazują środki w polskich złotych ${ }^{56}$.

Wśród osób, które nie przekazują zarobków na Ukrainę, jest duża grupa, która posiada oszczędności w Polsce (49,5\%). Część z nich planuje w przyszłości wrócić z zaoszczędzonymi pieniędzmi na Ukrainę $(45,4 \%)$. Poza osobami, które regularnie transferują środki na Ukrainę, istnieje zatem niemała grupa imigrantów, która jeszcze nie zdążyła tego zrobić, ale ma takie działania zaplanowane w perspektywie własnego powrotu. Największa część obywateli Ukrainy pracujących w aglomeracji warszawskiej $(64,9 \%)$ deklaruje, że istotna część przekazanych lub wywiezionych z Polski za granicę środków zostanie wykorzystana na bieżące wydatki. Kolejnym powszechnym celem jest zakup nieruchomości albo remont już posiadanego mieszkania czy domu (40,2\%),

55 I. Chmielewska, G. Dobroczek, J. Puzynkiewicz, Obywatele Ukrainy..., dz. cyt., s. 24.

56 I. Chmielewska, G. Dobroczek, J. Puzynkiewicz, Obywatele Ukrainy..., dz. cyt., s. 25. 
Wykres 5. Przyczyny zadowolenia z pracy w Polsce (dane w \%)

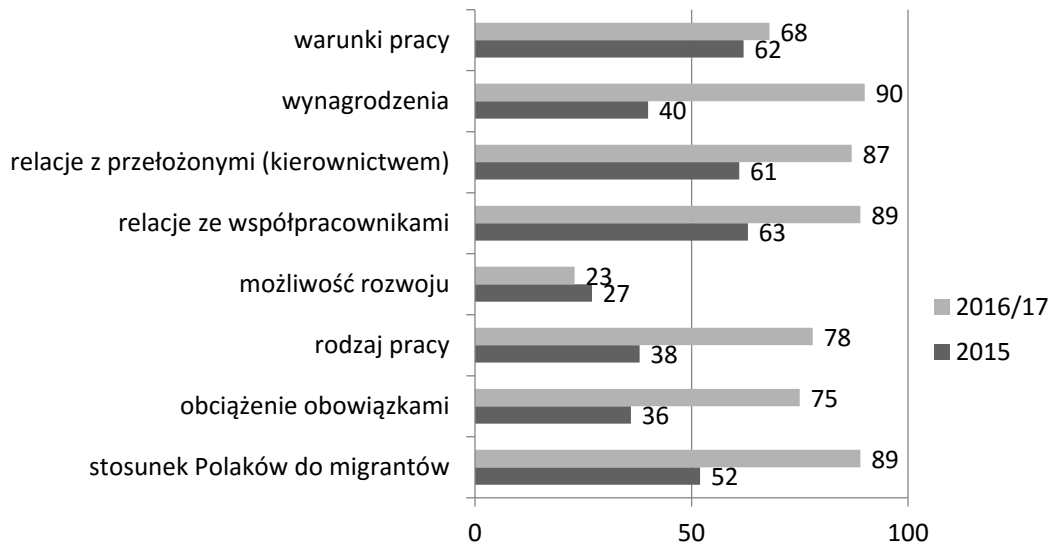

Źródło: отто Work Force

z czego większość (90,7\%) dotyczy remontu już posiadanej nieruchomości, a nie zakupu nowej. Nieco mniej badanych $(25,4 \%)$ transferuje swoje środki na cele zdrowotne. Sporo osób deklaruje również, że nie wyda wszystkiego. Zaoszczędzić część przekazanych pieniędzy planuje $31,4 \%$. Więcej ankietowanych zamierza zainwestować bardziej w edukację dzieci $(17,4 \%)$ aniżeli swoją $(3,9 \%)^{57}$.

Jeśli chodzi o część, jaka z przekazanych lub przewiezionych pieniędzy zostanie przeznaczona na dany cel, to tu ponownie dominują wydatki bieżące, które absorbują 31,7\% transferowanych środków. Na cele związane $z$ nieruchomościami ankietowani planują przeznaczyć 19,4\% przekazów, z czego większość (85,6\%) dotyczy remontów, a reszta zakupu mieszkania lub domu. Wśród innych wydatków, które zostaną sfinansowane z przekazów, istotne znaczenie mają także: cele zdrowotne $-8,7 \%$, edukacja dzieci $-6,9 \%$ oraz oszczędności - 14,6\%. $\mathrm{Na}$ finansowanie wydatków wskazanych w kategorii „inne” przezna-

57 I. Chmielewska, G. Dobroczek, J. Puzynkiewicz, Obywatele Ukrainy..., dz. cyt., s. 26. 
Wykres 6. Motywacja do pozostania w Polsce na stałe (dane w \%)

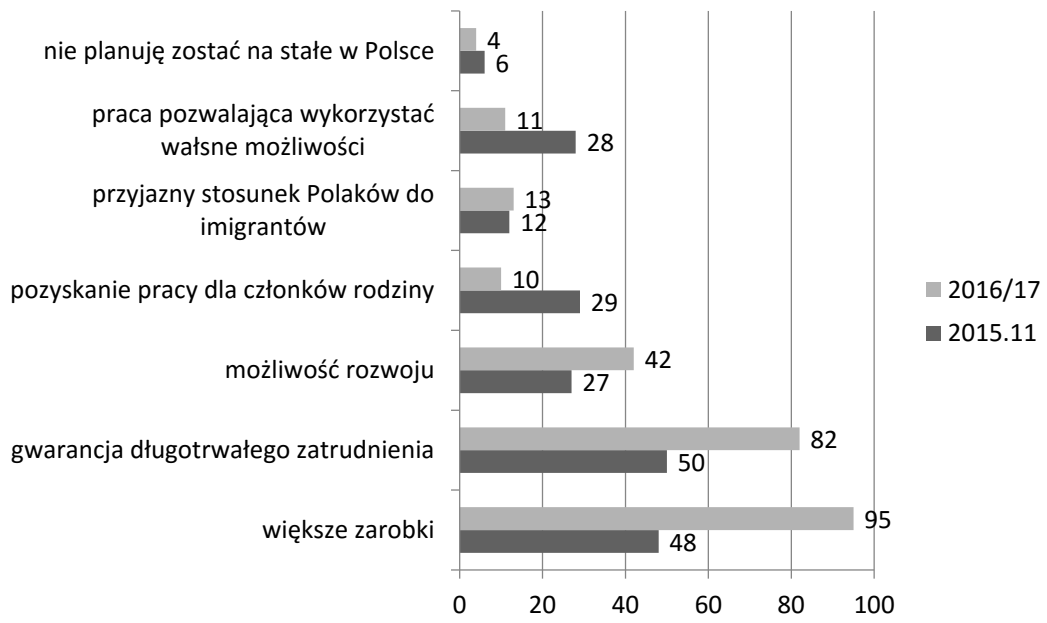

Źródło: otтo Work Force

czonych zostanie $18,7 \%$ transferów, z czego najwięcej $(23,2 \%)$ dotyczy spłaty długu ${ }^{58}$.

Jak pozwala wnioskować analiza zebranego materiału empirycznego, Ukraińcy rozważają pozostanie w Polsce na dłużej, a nawet na stałe. Najistotniejszym argumentem, który zachęciłby 95\% badanych pracowników z Ukrainy do pozostania w Polsce, są wyższe zarobki. Im pracownicy są starsi, tym większe znaczenie ma dla nich wysokość płac. Pozostałe elementy, które byłyby istotną zachętą, to: gwarancja długotrwałego zatrudnienia, która ważna jest dla 82\% pracowników z Ukrainy (wzrost w 2017 roku o 32\% w porównaniu z 2015 rokiem) oraz możliwość rozwoju ważna dla $42 \%$ badanych (wzrost o 15\% w porównaniu z 2015 rokiem). Im młodsi badani, tym ważniejsza jest dla nich możliwość rozwoju. Na znaczeniu straciło otrzymanie

58 I. Chmielewska, G. Dobroczek, J. Puzynkiewicz, Obywatele Ukrainy..., dz. cyt., 26-27 
Wykres 7. Ocena otwartości Polski na pracowników z Ukrainy (dane w \%)

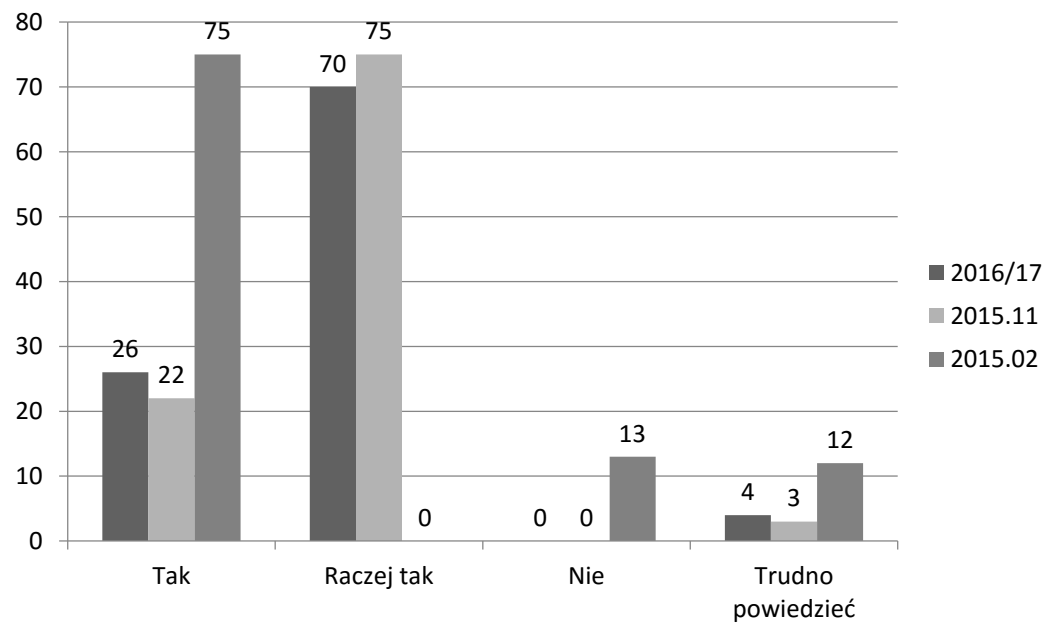

Źródło: отто Work Force

pracy pozwalającej wykorzystać w pełni możliwości (z 28\% do $11 \%$ w 2017 roku). Zmniejszyło się również z 29\% do 10\% znaczenie pozyskania w Polsce pracy dla członków rodziny. Stało się tak najprawdopodobniej dlatego, że praca w Polsce dla obywateli Ukrainy jest ogólnie dostępna ${ }^{59}$.

W analizowanych wynikach badań empirycznych znajdują się także dane dotyczące oceny Polaków i Polski jako kraju przyjmującego migrantów. Można na ich bazie wnioskować, że pracownicy z Ukrainy coraz lepiej oceniają otwartość Polaków wobec ich pobytu. W lutym 2015 otwartość Polski pozytywnie oceniło 75\% badanych, w listopadzie 2015 roku 97\%, w 2017 roku - 96\%. Wskaźniki należy ocenić jako wysokie. Ukraińcy ogólnie oceniają Polskę jako kraj otwarty na pracowników z Ukrainy.

59 T. Dudek, Raport: Opinia pracowników..., dz. cyt., s. 7. 


\section{Próba podsumowania}

Polska jest ważnym krajem migracji dla mieszkańców Ukrainy. Migracja ta jest uwarunkowana czynnikami społeczno-polityczno-ekonomicznymi. Jest ona korzystna dla polskiej gospodarki w sytuacji, gdy po wejściu do ue wielu Polaków opuściło swój kraj z powodów zarobkowych. Ukraińcy pracujący w Polsce to podobny odsetek kobiet i mężczyzn. Kobiety stanowią trzon tzw. starej migracji, pracują raczej w gospodarstwach domowych, mężczyźni zaś to ważna część nowej migracji zatrudnianej w usługach budowlano-remontowych. Wyraźnie widoczne staje się obniżenie wieku migrantów. Do Polski przyjeżdżają coraz młodsi Ukraińcy, którzy łączą pracę ze studiami. Dla nich polski etap w życiorysie to rozwój, możliwość zarobkowania, poznanie świata, kanał możliwego transferu do Europy Zachodniej. Odsetek osób starszych z każdym rokiem maleje.

Ukraińcy przebywający w Polsce to przede wszystkim pracownicy oraz studenci. Studiowanie w Polsce jest nową tendencją wśród najmłodszych migrantów z Ukrainy. Przyjeżdżający do pracy niejednokrotnie łączą pracę ze studiami, Polska zaś staje się w ich postrzeganiu coraz bardziej atrakcyjna jako miejsce stałego osiedlenia (w 2017 roku 48\% ogółu Ukraińców pracujących w Polsce zadeklarowało chęć stałego osiedlenia, a im lepiej wykształceni pracownicy, tym dłużej chcą pozostać w naszym kraju).

W grupie studentów z Ukrainy Polska postrzegana jest jako miejsce pracy, studiów, być może etap na drodze do dalszej migracji na Zachód. Dla 28,7\% przebadanych dochód z pracy jest głównym źródłem utrzymania w Polsce, a więc dla sporej części osób praca jest koniecznością. Ciekawe z punktu widzenia rynku pracy są też dalsze plany tej grupy respondentów. Spora ich część, bo aż 36,6\%, chciałaby pozostać w naszym kraju na stałe, a dalsze 32,5\% przynajmniej częściowo związać się z Polską. Pozostali studenci planują w przyszłości migrację do innego 
kraju (22\%). Jedynie niewielki procent $(2,4 \%)$ chciałby w przyszłości wrócić na Ukrainę, a reszta $(6,5 \%)$ nie ma jeszcze planów odnośnie do swojej przyszłości ${ }^{60}$.

Obserwowalny jest wzrost poziomu otwartości Polaków na pracowników z Ukrainy (wg opinii ukraińskich pracowników zebranych przez отто Work Force - z 75\% w 2015 roku do 97\% w 2017 roku). Wzrosło ogólne zadowolenie z pracy w Polsce pracowników z Ukrainy (z poziomu 84\% w 2015 roku do 94\% w 2017 roku). Aż 90\% pracowników z Ukrainy jest zadowolonych ze swojego wynagrodzenia (wzrost o 50\% w stosunku do 2015 roku). W 2017 roku 89\% pracowników było zadowolonych ze stosunku Polaków do pracowników z Ukrainy (wzrost o $37 \%$ w stosunku do 2015 roku). Podobny odsetek (89\%) pracowników jest zadowolony z relacji ze współpracownikami (wzrost o 26\% względem badania z 2015 roku). 87\% pracowników jest zadowolonych $\mathrm{z}$ relacji z przełożonym (wzrost o $26 \% \mathrm{w}$ stosunku do 2015 roku). $78 \%$ pracowników jest zadowolonych z rodzaju wykonywanej pracy (wzrost o 40\% w stosunku do 2015 roku). 75\% pracowników jest zadowolonych z obciążenia obowiązkami (wzrost o 39\% w porównaniu z badaniem Z 2015 roku). 68\% pracowników jest zadowolonych z warunków pracy (wzrost o 6\% w stosunku do $2015 \mathrm{roku}$ ). 23\% pracowników jest zadowolonych z możliwości rozwoju (w 2015 zadowolonych było 27\%). Dla $82 \%$ Ukraińców zachętą do pozostania w Polsce na stałe byłaby gwarancja długotrwałego zatrudnienia (wzrost o $32 \%$ w porównaniu z 2015 rokiem) oraz możliwość rozwoju - 42\% (wzrost o 15\% w porównaniu z 2015 rokiem). Im starsi pracownicy z Ukrainy, tym mniej są zadowoleni z wykonywanej pracy, obciążenia obowiązkami oraz możliwości rozwoju. 95\% pracowników z Ukrainy zachęciłyby do pozostania w Polsce większe zarobki. 29\% pracowników z Ukrainy pracuje zgodnie $\mathrm{z}$ własnym wykształceniem. To o $21 \%$ więcej niż

60 I. Chmielewska, G. Dobroczek, J. Puzynkiewicz, Obywatele Ukrainy..., dz. cyt. s. 30. 
w $2015 \mathrm{roku}^{61}$. Zadowolenie przejawia się w aktywności prospołecznej i budowaniu ukraińskich organizacji narodowych działających na rzecz Ukrainy $^{62}$.

Migranci podejmujący pracę w Polsce są generalnie dobrze i bardzo dobrze wykształceni. Znaczna ich część coraz częściej wykonuje pracę zgodnie ze swym poziomem wykształcenia. Ich pensje kształtują się na poziomie ok. 2000-2500 PLN (w 2017 roku średnia pensja „na rękę” wynosiła 2100 PLN $)^{63}$, zależnie od sektora zatrudnienia. Większość z nich, po odliczeniu kosztów „życia” (ok. 1/3 dochodów), dokonuje transferów finansowych na Ukrainę. Ekonomiści NBP oszacowali, że w 2015 roku Ukraińcy pracujący w Polsce krótkookresowo zarobili w sumie 8 mld PLN, a środki przekazane na Ukrainę wyniosły 5 mld PLN ${ }^{64}$.

Polska jest zatem od lat atrakcyjnym miejscem dla ukraińskich imigrantów zarobkowych. Ułatwienia z 2017 roku pozwalają na łatwiejszy wjazd do krajów Unii oraz skorzystanie z uproszczonych procedur uzyskania zezwolenia na pracę. Polska od wielu lat jest też naturalnym krajem emigracji zarobkowej Ukraińców, aczkolwiek tendencje te mogą zostać zmienione ze względu na brak spójnej polityki migracyjnej rządu Rzeczypospolitej wobec Ukraińców, utrudnień urzędniczych, a także otwarcie i ułatwienia dla Ukraińców ze strony Niemiec, Czech i Węgier. Otwarcie granic uE na Ukraińców, próby pozyskiwania pracowników z Ukrainy przez Niemcy, Czechy i Węgry może rodzić pytania o działalność polskiego rządu, o kształt polityki ekonomicznej i społecznej wobec migrantów z Ukrainy. Ważne wydaje się bowiem, by nie bazować jedynie na dotychczasowym stanie migracji i optymi-

61 T. Dudek, Raport: Opinia pracowników..., dz. cyt., s. 3.

62 Por. A. Korniychuk, Ł. Wenerski, Zaangażowanie społeczno-obywatelskie Ukraińców w Polsce, [w:] Zaangażowanie społeczne Ukrainców w Polsce i w Niemczech, red. A. Łady K. Böttger, Warszawa 2016, s. 35-86.

63 I. Chmielewska, G. Dobroczek, J. Puzynkiewicz, Obywatele Ukrainy..., dz. cyt., s. 4.

64 I. Chmielewska, G. Dobroczek, J. Puzynkiewicz, Obywatele Ukrainy..., s. 5. 
stycznych wynikach sondaży wśród Ukraińców pracujących w Polsce. W interesie relacji polsko-ukraińskich wydaje się leżeć wykorzystanie fali migracyjnej do budowania pozytywnych relacji między oboma narodami, dla polskiego rozwoju zaś ważna jest troska o jakość życia społeczno-ekonomicznego Ukraińców w Polsce. Imigranci zarobkowi mogą bowiem stanowić ogromny impuls do rozwoju gospodarki przyjmującego ich państwa. Wszystkie przesłanki wskazują na to, że właśnie tak dzieje się w przypadku Ukraińców przybywających do Polski. Należy zatem podjąć wszystkie możliwe działania sprzyjające mądrej absorpcji tych imigrantów. Niestety, wydaje się, że czas, w którym Polska była dla Ukraińców naturalnym wyborem miejsca migracji, mija. Obecnie Polska nie korzysta już w prosty sposób z fali imigrantów, chętnych do podjęcia zatrudnienia, ale uczestniczy w międzynarodowej konkurencji. Warto, by kluczowi decydenci nie tylko nie przeszkadzali przedsiębiorcom starającym się uzupełnić wakaty, ale by ze względu na fatalną sytuację demograficzną administrowali strumieniem imigrantów i nie utrudniali ich zatrudniania.

Inna trudność pojawiająca się w związku z migracją Ukraińców do Polski to aktywowane zaszłości historyczne. Rzeź wołyńska oraz postać Stepana Bandery różnicują i dzielą oba narodu. Odbija się to $\mathrm{w}$ relacjach między mniejszością ukraińską a Polakami: definiuje obcość Ukraińców w Polsce, naznacza pejoratywnie nazwę narodowości ukraińskiej, staje się składnikiem budującym stereotyp Ukraińca.

Najbardziej istotnym (najczęściej występującym i wywołującym największe emocje) tematem zebranych tekstów [internetowych] jest kwestia morderstw Polaków na Wołyniu w latach czterdziestych $\mathrm{xx}$ wieku. Po pierwsze, jest to ocena wydarzeń historycznych, po drugie, autorzy odnoszą się do współczesności i braku potępienia tamtych wydarzeń przez Ukrainę. Ten właśnie temat wywołuje najwięcej negatywnych wypowiedzi, znacząco wpływając na wydźwięk 
całego dyskursu dotyczącego Ukrainy. Kontrowersje wzbudza postać Stepana Bandery, w Ukrainie uznawanego za bohatera i żołnierza walczącego o niepodległość. Autorzy [badanych] postów dostrzegają nie tylko znaczenie Bandery dla ukraińskich ruchów nacjonalistycznych, ale również popularność tego bohatera w kulturze popularnej. $\mathrm{W}$ podobny sposób w polskim dyskursie traktowane są UPA i OUN ${ }^{65}$.

Przeszłość, gdy staje się elementem stereotypizującym, negatywnie naznacza całą grupę narodową i sprawia, że Ukraińcy przebywający w Polsce stawiani są w sytuacji odpowiedzialnych za historię oraz zło spraw bieżących ${ }^{66}$.

Generalnie sytuację Ukraińców pracujących w Polsce można ocenić pozytywnie. Polska stała się krajem naturalnego wyboru ich miejsca pracy oraz (czasowego) zamieszkania. Warunki społeczne i ekonomiczne swego pobytu sami Ukraińcy oceniają pozytywnie, warunki pracy, wynagrodzenie, jakość życia - są przez nich samych postrzegane pozytywnie. Analiza czynników zewnętrznych pozwala jednak stwierdzić, że na tym pozytywnym obrazie pojawiają się także rysy. To przede wszystkim brak polityki migracyjnej państwa w perspektywie otwarcia granic i prób pozyskiwania pracowników z Ukrainy przez Niemcy, Czechy i Węgry. To także zaszłości historyczne pomiędzy oboma krajami, które mogą być wykorzystywane przez stronę trzecią (Rosję) w celu poróżnienia obu narodów ${ }^{67}$.

65 M. Troszyński, Ukraina i Ukraińcy w polskim dyskursie internetowym. Analiza jakościowo-ilościowa tekstów zamieszczanych w mediach społecznościowych, [w:] Raport. Mniejszość ukraińska i migranci z Ukrainy w Polsce Analiza dyskursu, red. P. Tyma, Warszawa 2018, s. 105-106, http://naszwybir.pl/wp-content/uploads/2018/o3/raport_mniejszosc_ukrainska-ilovepdf-compressed-1.pdf (11.06.2018).

66 M. Troszyński, Ukraina i Ukraińcy w polskim dyskursie internetowym..., dz, cyt., s. 107-108.

67 Wicepremier Ukrainy ostrzega Polaków przed prowokacjami Rosji. „Wrogość sztucznie napędzana", http://wiadomosci.dziennik.pl/swiat/artykuly/544355,wicepremier- 


\section{Streszczenie}

Polska wydaje się naturalnym miejscem migracji zarobkowej Ukraińców. W ostatnich latach skala tej migracji znacznie się powiększyła. Ocenia się, że w Polsce przebywa i pracuje ok. 1,5 miliona obywateli Ukrainy. Znajdują oni zatrudnienie w sektorze budowlano-remontowym, gospodarstwach domowych, rolnictwie, handlu i gastronomii. Średnie dochody wynoszą ok 2.100 PLN netto. Sami Ukraińcy oceniają jakość pracy w Polsce dobrze lub bardzo dobrze. Ich pobyt jest motywowany ekonomicznie, możliwością znalezienia pracy stałej lub czasowej, ale także coraz częściej studiowaniem w Polsce i ogólnie rozumianym rozwojem. Znaczna większość z nich przesyła część zarobionych w Polsce pieniędzy na Ukrainę. Coraz większa część Ukraińców gromadzi osobiste oszczędności z myślą o stałym zamieszkaniu w Polsce. Obok tych pozytywnych faktów istnieją także trudności. Są to przede wszystkim różnice w interpretacji trudnych wydarzeń historycznych. Część Polaków za brak wyjaśnienia tych różnic obciąża odpowiedzialnością mniejszość ukraińską w Polsce. Zaszłości historyczne coraz częściej stają się budulcem negatywnego stereotypu Ukraińca. Drugą trudnością jest brak polityki migracyjnej wobec mniejszości ukraińskiej. W sytuacji swobodnego przepływu pracowników W UE może to grozić przejęciem pracowników z Ukrainy przez gospodarki Niemiec, Czech i Węgier.

Słowa kluczowe: migracja, migracja zarobkowa, transfery pieniężne, Ukraińcy

\section{Summary}

Socio-economic situation of Ukrainians in Poland

Poland seems to be a natural place for labor migration of Ukrainians. In recent years, the scale of this migration has increased significantly. It is estimated that about 1.5 million Ukrainian citizens live and work in Poland. They find employment in the construction and renovation sector, in the household, agriculture, trade and gastronomy. The average income is about PLN 2,100 net. The Ukrainians themselves assess the quality of work in Poland well or very well. Their stay is economically motivated, the possibility of finding permanent

-ukrainy-wiaczeslaw-kyrylenko-polska-ukraina-prowokacje-rosyjskie-rosja.html (11.06.2018). 
or temporary work, but also more and more often studying in Poland and generally understood development. The vast majority of them send part of the money earned in Poland to Ukraine. An increasing number of Ukrainians are accumulating personal savings with a view to permanent residence in Poland. In addition to these positive descriptions, there are also difficulties. These are primarily differences in the interpretation of historical events. Some Poles, for lack of explanation of these differences, are responsible for the Ukrainian minority in Poland. Historical events are increasingly becoming the building blocks of the Ukrainian's negative stereotype. The second difficulty is the lack of Polish migration policy towards the Ukrainian minority. In the situation of free movement of employees in the EU, this may be a threat to the takeover of employees from Ukraine by the German, Czech and Hungarian economies. Keywords: migration, labor migration, money transfers, Ukrainians 